This is an electronic reprint of the original article. This reprint may differ from the original in pagination and typographic detail.

Author(s): Ojala, Arto

Title: Internationalization of knowledge-intensive SMEs: The role of network relationships in the entry to a psychically distant market

Year: $\quad 2009$

Version:

Please cite the original version:

Ojala, A. (2009). Internationalization of knowledge-intensive SMEs: The role of network relationships in the entry to a psychically distant market. International Business Review, 18(1), 50-59. https://doi.org/10.1016/j.ibusrev.2008.10.002

All material supplied via JYX is protected by copyright and other intellectual property rights, and duplication or sale of all or part of any of the repository collections is not permitted, except that material may be duplicated by you for your research use or educational purposes in electronic or print form. You must obtain permission for any other use. Electronic or print copies may not be offered, whether for sale or otherwise to anyone who is not an authorised user. 


\title{
Internationalization of knowledge-intensive SMEs: The role of network relationships in the entry to a psychically distant market
}

\author{
Arto Ojala \\ University of Jyväskylä \\ Finland
}

\begin{abstract}
Current research emphasizes the role of extant network relationships in the international development of SMEs. Inevitably, these relationships are there, most likely, to provide linkages with and facilitate entry into psychically and geographically close markets. But what of firms entering psychically distant markets, for strategic reasons, as is usually the case with knowledge-intensive SMEs? Will existing network relationships remain important, and will they operate in a similar way. In this exploratory case study, in which eight Finnish software SMEs enter the Japanese market, the decision to enter these markets is found to be for strategic reasons rather than in order to follow network relationships. In addition, the way to enter these markets is not seen influenced by extant business relationships. It seems more reasonable to argue that the important relationships were actively utilized or developed to achieve the market entry, and were, in many cases, mediated relationships with non-profit government-owned consulting firms.
\end{abstract}

KEYWORDS: Networks, Internationalization, Market entry, Software firms, Psychic distance, Knowledge-intensive firms, Finland, Japan, Case study

\section{Introduction}

The importance of network relationships on firms' internationalization behavior has been highlighted in several studies. Especially in research related to small and medium-sized enterprises (SMEs) in knowledge-intensive sectors, these network relationships between firms or individuals have been seen as determinants of internationalization (Coviello, 2006; Coviello \& Munro, 1995, 1997; Coviello \& Martin, 1999; Sharma \& Blomstermo, 2003; Moen et al., 2004; Zain \& Ng, 2006). These studies have commonly challenged earlier incremental internationalization models (Bilkey \& Tesar, 1977; Cavusgil, 1980; Johanson \& Vahlne, 1977; Johanson \& Wiedersheim-Paul, 1975; Luostarinen, 1979) by suggesting that a network model of internationalization (Johanson \& Mattsson, 1988) can better explain the internationalization behavior of knowledge-intensive SMEs.

In current literature, researchers (Coviello \& Munro, 1995, 1997; Coviello \& Martin, 1999; Moen et al., 2004; Zain \& Ng, 2006) have found that network relationships have a significant impact on knowledge-intensive SMEs' market and entry mode choice. In these studies, firms' network relationships have been seen as the major initiators in the internationalization process where firms are following their networks to foreign markets. This is in line with the assumption 
in the network model (Johanson \& Mattsson, 1988) that the network relationships can act as a bridge to foreign markets. However, studies related to knowledge-intensive SMEs have analyzed a general pattern of entry where firms commonly follow their formal or informal network relationships to nearby, psychically close markets ${ }^{1}$. However, in many cases, knowledge-intensive SMEs are forced to enter psychically distant markets for strategic reasons to reach opportunities for their niche products (Bell et al., 2003; Ojala \& Tyrväinen, 2007; Ojala, 2008). Thus, it remains unclear what roles the different types of network relationships may have, and whether these are operationalized in a similar manner when a firm enters to psychically distant markets.

For the reasons above, this study is aimed to analyze firms' activities in developing network relationships, their focal ${ }^{2}$ network relationships, and the impact of these relationships to the market and entry mode choice of knowledge-intensive SMEs when they enter a psychically distant market for their products. Finnish software firms in the Japanese market were selected as a suitable target group that addresses the concerns of this study. Japan can be characterized as the 'leading market' for foreign knowledge-intensive SMEs (Bell et al., 2003; EITO, 2006) due to its attractiveness and market size. It is not, however, commonly seen as the target country for initial market entries. Thus, there is a tradeoff between the attractions of the market and averseness to psychic distance. This study contributes to the network theory in the context of internationalization of knowledge-intensive SMEs by analyzing market entries in settings where firms are entering an attractive but psychically distant market for their products. The following three questions in the context of market entry to the Japanese market are of particular interest in this study:

1) What are the network approaches used by knowledge-intensive SMEs entering distant markets?

2) What are the different types of focal relationships used by knowledge-intensive SMEs to enter distant markets?

3) How is the market entry of knowledge-intensive SMEs into a distant market affected by different types of focal network relationships?

\section{Literature Review}

The literature related to networks and internationalization of firms is both rich and extensive and includes several types of approaches to investigate the phenomenon. In addition, networks have been widely used to explain the internationalization of firms in various industry segments. To specify the focus of the literature review discussed here, network approaches for entering foreign markets are presented first. The second sub-section presents different types of network relationships used for foreign market entry. Thereafter, the influence of the network relationships on market entry and entry mode choice of knowledge-intensive SMEs is elaborated. The end of the chapter summarizes the literature and highlights those issues that the current studies related to this topic do not explain adequately.

\footnotetext{
${ }^{1}$ Psychically close in these studies refers to the definition of Johanson and Wiedersheim-Paul (1975) that conceptualize the psychic distance as similarities in language, culture, political system, level of education, level of industrial development etc. between two countries.

${ }^{2}$ The term focal relationship refers here to the most important contact as the key informant that enabled a firm's entry into the distant market.
} 


\subsection{The network approaches for entering foreign markets}

The network model of internationalization was presented in the 1980s when it became evident that most of the firms used various networks to facilitate their internationalization activities (Johanson \& Mattsson, 1988) ${ }^{3}$. The main distinguishing factor between incremental internationalization models, such as the Uppsala model (Johanson \& Wiedersheim-Paul, 1975), and the network model is that the network model is not gradually progressing in nature. Moreover, the network model says nothing about psychic distance or the countries a firm is entering into. Instead, it conceptualizes internationalization as being related to relationships establishment and building (Johanson \& Vahlne, 2003). According to Johanson and Mattsson (1988), a firm is dependent on resources controlled by other firms and can get access to these resources by developing its position in a network. In these networks, firms have common interests in developing and maintaining relationships with each other in a way that provides them mutual benefits (Johanson \& Mattsson, 1988, 1992; Johanson \& Vahlne, 2003).

In the model (Johanson \& Mattsson, 1988), internationalization occurs when a firm starts to develop relationships with another firm that belongs to a network in a foreign country. Relationships between the firms in different countries act as a bridge to new markets (Johanson \& Vahlne, 1990). Development of these relationships with other actors in the market can be active or passive. In active networking, the initiative is taken by the seller, whereas in passive networking the initiation comes from the buyer's direction (Johanson \& Mattsson, 1988). The importance of active networking for learning, knowledge acquisition, foreign expansion, etc. is indicated in several studies (Gabrielsson et al., 2008; Gilmore et al., 2006; Loane \& Bell, 2006). For instance, the study of Loane and Bell (2006) shows that a firm without suitable network relationships can take an active role and build new connections to facilitate its market entry. Passive networking is the result of an initiative taken by another actor, such as a customer, importer, intermediate, or supplier (Ellis, 2000; Johanson \& Vahlne, 2003) that can open new opportunities in foreign markets. Empirical findings related to internationalization of knowledge-intensive firms have indicated that these firms have a more passive role in networking because they tend to be lead to foreign markets by their existing networks (Bell, 1995; Coviello \& Munro, 1995, 1997; Coviello \& Martin, 1999; Moen et al., 2004; Sharma \& Blomstermo, 2003; Zain \& Ng, 2006).

Summarizing, the network approaches for entering new markets can be divided into active networking and passive networking. The active networking refers to the situation where initiation for networking is taken by the seller. In contrast, in the passive networking, the initiation for networking comes from outside of the firm.

\subsection{The different types of network relationships used for entering foreign markets}

According to the network model of internationalization (Johanson \& Mattsson, 1988), a firm can have relationships with various actors, including customers, distributors, suppliers, competitors, non-profit organizations, public administration, and so on. The different types of network relationships for entering foreign markets can be divided into formal, informal (Birley, 1985; Coviello \& Munro, 1995, 1997; Coviello \& Martin, 1999; Dubini \& Aldrich, 1991; Harris \& Wheeler, 2005; Rialp et al., 2005; Westphal et al., 2006), and intermediary (Ellis \& Pecotich, 2001; Chetty \& Blankenburg Holm, 2000; Havila et al., 2004; Oviatt \& McDougall,

\footnotetext{
${ }^{3}$ The model is further developed in the studies of Johanson and Vahlne (1990, 1992, 2003)
} 
2005). However, the literature related to types of network relationships is somewhat confusing. For instance, Birley (1985) proposes that formal relationships are related to financial sources available whereas informal relationships refer to contacts between other business actors, friends, and family members. In contrast, the study of Dubini and Aldrich (1991) suggests that extended (formal) relationships consist of relationships between all the employees of each firm whose role is boundary-spanning whereas personal (informal) networks are related to all persons that an entrepreneur can meet directly.

Despite this vagueness, a common agreement in the current literature seems to be that while formal relationships are related to business activities between two or more actors in the network, the informal relationships are related to personal relationships with family members and friends (Coviello, 2006; Coviello \& Munro, 1995, 1997; Coviello \& Martin, 1999; Harris \& Wheeler, 2005; Sharma \& Johanson, 1987; Westphal et al., 2006). In addition to formal and informal relationships, several researchers (e.g., Ellis \& Pecotich, 2001; Havila et al., 2004; Oviatt \& McDougall, 2005) have indicated the importance of intermediary relationships. In intermediary relationships, there is no direct contact between the seller and the buyer. However, there is an actor, as a third party, that facilitates the establishment of the network relationship between the buyer and the seller. According to Oviatt and McDougall (2005) these "brokers" can provide links between actors in different markets and consequently initiate international business activities between the seller and the buyer.

To conclude, the different types of focal network relationships for entering new markets can be divided into formal relationships, informal relationships, and intermediary relationships. The formal relationship refers to the relationship with other business actors whereas informal relationships are related to social contacts with friends and family members. In the intermediary relationship, there is a third party that connects the buyer and the seller.

\subsection{The influence of network relationships on how markets are entered}

The network model of internationalization says nothing about how markets are entered in terms of geographical or psychic distance or how network relationships impact the entry mode choice in a target country (Johanson \& Mattsson, 1988; Johanson \& Vahlne, 2003). However, several studies related to internationalization of knowledge-intensive SMEs (Bell, 1995; Coviello, 2006; Coviello \& Munro, 1995, 1997; Coviello \& Martin, 1999; Crick \& Spence, 2005; Moen et al., 2004; Sharma \& Blomstermo, 2003; Zain \& Ng, 2006) have indicated that networks have a strong impact on market and/or entry mode choice. These studies seem to agree in that knowledge-intensive SMEs firms enter geographically and/or psychically nearby markets by following their existing network relationships. The studies of Coviello and Munro $(1995,1997)$ concerning New Zealand based small software firms imply that a firm's formal and informal network relationships first give it an access to psychically close markets and determine its mode of entry. However, in time, these formal and informal relationships also facilitate market entry to psychically distant markets. These findings are consistent with the study of Coviello and Martin (1999), where the authors indicate the important role of formal and informal relationships in firms' initial market selections and entry mode choices to geographically nearby markets. In line with these earlier studies, Moen et al. (2004) and Zain and Ng (2006) found that network relationships have an impact on the entry mode and market selection of small software firms, and thus, influence the internationalization process of these firms. Moen et al. (2004) also argue that small software firms first internationalize to psychically nearby countries, later market choices being less dependent on psychic distance. They propose, 
nevertheless, that psychic distance might have a more important role in non-English speaking countries. In contrast, although the study of Sharma and Blomstermo (2003) found support to the argument that the internationalization process of knowledge-intensive SMEs is influenced by network relationships, they indicate that entry mode choice is based on the requirements of the market and the client in question. This is consistent with the study of Bell (1995) indicating that although small software firms tend to internationalize their operations first to countries with a low psychic distance by following their customers and using contacts with foreign customers, their entry mode choice is more related to the complexity of software products.

In literature, there seems to be some disagreement about how firms can utilize their network relationships when entering new markets. For instance, the study of Crick and Spence (2005) indicates that although knowledge-intensive firms are capable of using existing networks to increase their business activities in existing markets, they can only use these relationships to a limited extent when entering new markets. This is in line with Bell (1995) arguing that the network model of internationalization is incapable of explaining the internationalization of firms without network contacts to particular markets. Zain and $\mathrm{Ng}$ (2006) also emphasized that market entry of knowledge-intensive SMEs is more related to the already existing opportunities created by network relationships than to strategic decisions by managers. In contrast, the study of Loane and Bell (2006) found that firms without suitable network relationships actively built new connections which facilitated their market entry.

Finally, current studies indicate that different types of network relationships have a strong influence on how markets are entered by knowledge-intensive SMEs. The common agreement seems to be that these firms tend to follow their formal or informal relationships to nearby markets. The choice of an entry mode for a market is also commonly seen as a consequence of these network relationships, although some studies (Bell, 1995; Sharma \& Blomstermo, 2003) have challenged this.

\subsection{Summary and critique to the literature}

Current studies have discovered support for the claim that the network model of internationalization (Johanson \& Mattsson, 1988) is applicable, to some extent, to explain the internationalization of knowledge-intensive SMEs. These studies (Bell, 1995; Coviello, 2006; Coviello \& Munro, 1995, 1997; Coviello \& Martin, 1999; Crick \& Spence, 2005; Moen et al., 2004; Sharma \& Blomstermo, 2003; Zain \& Ng, 2006) have mainly described the general pattern of entry where firms enter nearby, psychically close markets by following their formal or informal network relationships. Thus, there is very little indication in these studies about what the role of network relationship is when a firm enters a distant market for their products a common practice after their initial entries to nearby markets (Ojala, 2008; Ojala \& Tyrväinen, 2007). The important thing to find out now is whether there are differences in the networking behavior when firms enter to a psychically distant market.

\section{Research Method}

Following suggestions by Eisenhardt (1989) and Yin (1994), the multiple case study method was selected for this study due to the exploratory nature of the research question. Eisenhardt (1989) argues that multiple case study enables studying patterns that are common to the cases and theory under investigation. The case study method also makes it possible to explain the significance and cause-and-effect relationships of the examined phenomena (Yin, 1994). 
The case firms selected satisfied the following criteria: they a) have their headquarters in Finland, b) have direct business operations in the Japanese market, c) are doing business in the field of software, and d) have a maximum of 500 employees worldwide. Suitable firms for this study were identified from the websites of the Finnish Chamber of Commerce in Japan and Finnish Software Business Clusters, as well as from a list of firms in the publication "Software Product Business Cluster in Finland 2005". By using these sources a total of nine suitable firms were identified. These firms were contacted with an e-mail request to attend the research. Eight of the nine firms responded and were willing to share their knowledge and experience of the Japanese market.

In this study, the case firms were selected based on the definition of SMEs, i.e., firms with 500 or fewer employees at the time of interviews. However, the case firms identified for this study fit also pretty well to the Finnish government's and European Union's definition for SMEs as firms with less than 250 employees (OECD, 2003), due to the reason that only one of the case firms had more than 250 employees at the time of the interviews. In fact, when this firm started their internationalization to the Japanese market, they had only 205 employees.

Software firms have commonly been used as a target group when analyzing internationalization of knowledge-intensive SMEs (see e.g., Bell, 1995; Coviello, 2006; Coviello \& Munro, 1995, 1997; Moen et al., 2004; Zain \& Ng, 2006). This has been mainly for the reason that the intangible nature of product, low reproduction costs, virtually nonexistent production, electronic distribution, and dependence of adequate knowledge (Almor \& Hashai, 2004) within these firms presents a challenge to the existing internationalization theories. Focusing on one single sector in this study helps to complement existing studies related to the software industry and reduces the potential for confusing results (Zahra \& Bogner, 2000).

In this study, Finland was chosen as the country of origin due to its small and open economy with a very limited domestic market. For Finnish high-technology SMEs, internationalization is generally a common growth strategy (Autio et al., 2000). Japan was chosen as the target country for the following reasons: First, according to EITO (2006), Japan is the world's second largest market for software products. Thus, Japan presents one of the leading markets (Bell et al., 2003) for software firms. This makes Japan a very attractive country for foreign software firms. Secondly, due to the differences in culture, language, and business practices between Finland and Japan, Japan can be ranked as a psychically distant country from Finland (Karppinen, 2006; Peltokorpi, 2007; Ronen \& Shenkar, 1985). A large psychic distance between two countries makes the market entry very challenging, as indicated in traditional internationalization theories (Bilkey \& Tesar, 1977; Cavusgil, 1980; Johanson \& Vahlne, 1977; Johanson \& Wiedersheim-Paul, 1975). Furthermore, Lu and Beamish (2001) indicate that a large difference between countries makes the market entry more entrepreneurial in nature. Thirdly, choosing Finnish software firms in Japan enabled addressing the target group, to a large extent by using a qualitative case-study method.

Interviews were conducted with managers in each firm's headquarters in Finland and their units in Japan covering altogether 16 interviews. All executives (CTO, Director, Executive Vice President, President, Managing Director, Sales Administrator) interviewed had an in-depth knowledge of their firms' international operations and entry into the Japanese market. These professions correspond to those of informants that are commonly used in the field of international entrepreneurship (see Coviello \& Jones, 2004). In addition, executives interviewed had the key position in the network development for the market entry to Japan.

In the interview process, the semi-structured open-ended interviews were conducted. This enables asking about the main questions and then make further, more detail questions (Yin, 
1994). Interviewees were first asked to describe their business in general and thereafter as related to Japan particularly. Based on this general information, more detailed questions were asked about their firm's market entry into the Japanese market. These questions were divided into themes, and the interviewees were asked to tell about the following issues: 1) The firm's activity in the networking process for the Japanese market entry 2) important events, persons, firms, or organizations that influenced the market entry to Japan 3) the importance of the Japanese market for the firm's products, and 4) the impact of other actors for the market entry and entry mode choice in the Japanese market. All these themes were developed by following the guidelines of Yin (1994), trying to make the questions as non-leading as possible. This allowed the interviewees to give genuine answers to the questions during the interviews.

These 60-90 minutes long interviews were digitally recorded, carefully listened to, and transcribed verbatim with the help of a word processor. A second listening was conducted to ensure correspondence between the recorded and transcribed data. Complete case reports were sent back to the persons interviewed to ensure validity and authenticity of the collected data. Whenever interviewees in the case firms found some inaccuracies in the text, these were corrected based on their comments. In addition, some telephone and e-mail interviews were used to collect further information from the interviewees. The collected data was also compared with other sources, such as websites and annual reports of the case firms.

In the data analysis, guidelines suggested by Eisenhardt (1989) and Yin (1994) were followed. All eight individual cases were written out as standalone case histories. After that, the unique patterns of each case were identified and similar patterns categorized under common themes. This helped to organize and summarize the collected data. In addition, analytical tools were applied within and across the cases as proposed by Miles and Huberman (1994). For instance, checklists and event listings were used to identify critical events related to market entry and networking of each case firm. In the analyzing process, the firms' activity in the networking process was analyzed as being either active or passive according to the network model of internationalization (Johanson \& Mattsson, 1988). If the case firm took the initiative to network for the purpose of market entry it was classified as 'active' whereas if the initiative came from outside of the firm it was classified as 'passive'. The network relationships used for the market entry were categorized into formal, informal, and mediated and were based on focal relationships, which refer to the most important contact like the key informant (see Anderson et al., 1994) that opened the firm's way into the Japanese market.

The average number of employees in the case firms was 127. All the case firms were established between 1990 and 2000, except for Firm C that was established already in 1966. The firms had operated in the Japanese market from three to seven years. Table 1 summarizes key information for the case firms and demonstrates their foreign direct investments until the market entry to Japan. Entry modes used by each case firm in Japan are presented in a chronological order. In addition, the case firms' target industry segments in Japan are indicated. 
Table 1

Key information on the case firms

\begin{tabular}{|c|c|c|c|c|c|}
\hline & $\begin{array}{l}\text { Number of } \\
\text { employees }\end{array}$ & $\begin{array}{c}\text { Year of } \\
\text { establishment }\end{array}$ & $\begin{array}{c}\text { Foreign direct business } \\
\text { operations }\end{array}$ & Entry modes in Japan & $\begin{array}{c}\text { Target industry } \\
\text { segment in Japan }\end{array}$ \\
\hline Firm A & 30 & 1998 & $\begin{array}{c}\text { USA } 1998 \\
\text { Hungary } 2000 \\
\text { Japan } 2002\end{array}$ & Representative 2002 & $\begin{array}{l}\text { Mobile phone } \\
\text { manufacturers, } \\
\text { telecom operators, } \\
\text { and electronics } \\
\text { industry }\end{array}$ \\
\hline Firm B & 90 & 1992 & $\begin{array}{l}\text { USA } 2000 \\
\text { Japan } 2002\end{array}$ & Representative office 2002 & $\begin{array}{l}\text { Mobile phone and } \\
\text { semiconductor } \\
\text { manufacturers }\end{array}$ \\
\hline Firm C & 300 & 1966 & $\begin{array}{c}\text { Sweden } 1995 \\
\text { USA } 1999 \\
\text { Malaysia } 1999 \\
\text { Germany } 1999 \\
\text { UK } 1999 \\
\text { Japan } 2000\end{array}$ & $\begin{array}{l}\text { Distributors } 1999 \\
\text { Representative office } 2000 \\
\text { Subsidiary } 2001\end{array}$ & $\begin{array}{l}\text { Building and } \\
\text { construction industry }\end{array}$ \\
\hline Firm D & 240 & 1990 & $\begin{array}{l}\text { USA } 1998 \\
\text { Japan } 1999\end{array}$ & $\begin{array}{l}\text { Representative office } 1999 \\
\text { Subsidiary } 2000\end{array}$ & $\begin{array}{l}\text { Banks, financial } \\
\text { institutions, Internet } \\
\text { operators }\end{array}$ \\
\hline Firm E & 100 & 1995 & $\begin{array}{l}\text { USA } 1998 \\
\text { Japan } 2000\end{array}$ & $\begin{array}{l}\text { Direct sales } 1999 \\
\text { Subsidiary } 2000\end{array}$ & $\begin{array}{l}\text { Banks, financial } \\
\text { institutions, fortune } \\
500 \text { companies }\end{array}$ \\
\hline Firm F & 210 & 1991 & $\begin{array}{c}\text { Sweden } 1999 \\
\text { Hong Kong } 2000 \\
\text { Japan } 2001\end{array}$ & $\begin{array}{l}\text { Distributor } 1997 \\
\text { Joint Venture } 2001 \\
\text { Subsidiary } 2005\end{array}$ & $\begin{array}{l}\text { Telecom operators, } \\
\text { R\&D companies } \\
\text { related to mobile } \\
\text { networks }\end{array}$ \\
\hline Firm G & 12 & 1998 & Japan 1999 & Joint venture 1999 & Mobile game players \\
\hline Firm $\mathrm{H}$ & 35 & 2000 & $\begin{array}{l}\text { UK } 2000 \\
\text { Japan } 2003\end{array}$ & Corporate 2003 & $\begin{array}{l}\text { Video game players } \\
\text { in broadband } \\
\text { networks }\end{array}$ \\
\hline
\end{tabular}

\section{The network approaches used by the case firms}

The network approach used by the case firms can be described either as active or passive. In total, six out of eight case firms were actively developing their networks to reach opportunities in the Japanese market. This was due to the large market size and sophisticated industry structure for those firms' products. Firms A, C, E, and F were actively searching business opportunities from the Japanese market due to the huge market potential for their niche products. However, although the Japanese market proved very attractive, they did not have any existing formal or informal relationships that they could use for entering the market. Despite of that, these firms took an active role and built networks actively with non-profit consultancy organizations. These relationships acted as focal relationships for networking with customers or distributors in Japan and were the contacts of prime importance for these firms. Firms D and H, who were able to utilize their existing formal relationships with other firms for the market entry, were also actively seeking opportunities from the Japanese market. For instance, Firm D used their current business relationships with a large international firewall provider. By using this 
relationship, they got access to the same distribution channel that their partner was using in Japan. One informant at Firm D explained this in the following way:

"Because our products were interlinked with their products, we were able to utilize their already existing contacts and distribution channels [in Japan]. We recruited the same persons who were selling their products to sell our products. It was reasonable, because the distribution channel worked well and we got contacts very easily established."

Two of the case firms ( $B$ and $G$ ) had a more passive role in their market entry to Japan, although they recognized Japan as a very attractive market for their products. In both cases, the initiation for the market entry came from managers' friends from earlier businesses (informal relationships). As an example, Firm B's manager's friend from a firm located in the UK was in contact with joint business opportunities in Japan. The manager of Firm B expressed this as follows:

"They [the firm from the UK] wanted to get one large Japanese firm as their customer, but their potential customer in Japan liked to have also a software product that only we can provide. Thus, they [the firm from the UK] introduced us to this Japanese firm and we got into the market very nicely".

\section{The focal network relationships of the case firms}

The findings from the eight case firms revealed that the market entry into the Japanese market was facilitated by formal, informal, and mediated relationships. Firms D and H that used formal relationships were able to use their existing business relationships with their distributors in other markets. For instance, Firm $\mathrm{H}$ used their existing, formal relationships with their distributor, who marketed and sold their products worldwide, for their market entry. With the help of this relationship, they found a large Japanese corporation interested in their software. One informant at Firm H explained this as follows:

"Our distributor who had good sales networks and offices in London, Tokyo, and the US helped us. Compared to us, they had a totally different admission to these markets, and they opened our way to the Japanese market"

Firms $B$ and $G$ used relationships with their friends in other countries (informal relationships) for their market entry. Friendships had already been established in their former jobs, and there was no existing business activity between them. As an example of the impact of informal relationships, Firm G's entry to the Japanese market was initiated by their management team's Japanese friends. These friends from earlier jobs realized that Firm G's game solutions had a huge market potential in Japan and invited the firm into the Japanese market. One informant at Firm $\mathrm{G}$ explained this in the following manner:

"We had long-term personal relationships from our earlier businesses with persons

in Japan. They had a good position and demonstrated willingness to establish this

kind of company [joint venture]. So from the establishment phase on, these persons

were involved, and it [joint venture] was established from their initiative."

Mediated relationships were important for those firms (A, C, E, and F) that did not have any existing formal or informal relationships that they could use for their market entry. These firms developed networks with non-profit consultancy organizations in the home and/or the host country which enabled networking with potential distributors for market entry. These kinds of mediated relationships opened the way to the Japanese market and helped these firms with further networking with customers and/or distributors in Japan. As an example of this, Firm A 
had no available formal or informal relationships to utilize for the market entry to Japan. For this reason, they contacted a Finnish non-profit consultancy firm, and with the help of this consultancy firm they started to search suitable distributors from Japan. By using this relationship, they were able to identify a distributor that started to deliver their products in the Japanese market. One informant at Firm A described this as follows:

"Japan is very difficult market to enter...We started a cooperation project with

Finpro [Finnish non-profit consultancy association], where they searched a distributor that would be beneficial for our purposes. We also participated in Finpro's export partnership visit to Japan and it helped us to find the right distributor for our purposes."

Table 2 summarizes the case firms' activity and focal relationships in the market entry.

Table 2

The focal relationships and firms' activity in market entry

\begin{tabular}{lccc}
\hline & $\begin{array}{c}\text { Formal } \\
\text { Relationship }\end{array}$ & Informal relationships & $\begin{array}{c}\text { Mediated } \\
\text { relationships }\end{array}$ \\
\hline Active & D, H & - & A, C, E, F \\
Passive & - & B, G & - \\
\hline
\end{tabular}

\section{The influence of the network relationships on the entry into the Japanese market by the case firms}

The case findings indicate that the different types of focal network relationships only had limited influence on the choice of target country and entry mode. Regarding the country selection, most of the firms had made a strategic decision to enter the Japanese market before they had started to actively search for network relationships to achieve the market entry (see Table 3). Thus, all the firms, excluding firms B and G, selected the market without any influence of network partners. This was mainly because the Japanese market was seen as the major market for the firms' niche products. As an example, Firm H developed gaming-ondemand solutions and content for broadband networks. Use of their products requires highly developed and fast broadband networks, which were not available in Europe or the US at the time of the market entry to Japan. In this respect Japan offered the most sophisticated markets for their products. One informant at Firm $\mathrm{H}$ commented their reason for the market entry in the following way:

"From the beginning, Japan was our first target... because the nature of our product, if we think about it, is technology used in videogames, including the aspect of broadband. The markets where these both [markets for videogames and broadband connections] are advanced are Japan and South-Korea."

For firms A, C, D, E, and F, the large size of their target industry in Japan was the main initiator for the market entry. An informant from Firm E commented the importance of the Japanese market in the following manner:

"Japan became a potential target country very early on. We started searching business potential there. There is a lot of manufacturing and there are large firms that develop and use IT-related technology; thus there are numerous target customers." 
As an another example, an interviewee from Firm $\mathrm{C}$ indicated the market potential in the Japanese market for their modeling software that was targeted to steel and concrete construction industries as follows:

"Steel construction, that is one of our main target industry...it has a very remarkable role in Japan. This is because Japan is located in a seismic zone - so they use a lot of steel as a construction material. In this respect, the Japanese market is equal with the US market. "

A stronger influence of network relationships on the target country choice became evident in the passive market entry, where initiation into the market came through existing, informal relationships (Firms B and G). While, in these cases, the Japanese market was also recognized as a potential market for the firms' products, the informal relationships opened the way into the Japanese market. For instance, the market entry of Firm B was strongly influenced by existing, informal relationships with managers of a firm located in the UK. This British firm opened Firm B's way to the Japanese market, although they saw Japan as a potential target for their own software products.

In addition to target country selection, the case findings give only limited support to the impact of different types of network relationships on entry mode choice. The entry mode choice of the other five case firms (A, B, C, D, and E) was based on their product strategy and requirements for implementation and after-sales support instead of network relationships. In these cases, an own unit in the market proved important due to the complex nature of the software products, which required close cooperation with customers and/or distributors throughout the product life-cycle, including sales process, implementation, and after-sales support. For instance, Firm A decided to enter the market by using a distributor found with help of a mediated relationship. However, they had to send a representative to that market, because selling of their products with the help of a distributor proved impractical due to the complexity of their products. As another example, Firm B decided to establish a representative office in Japan, because it enabled close cooperation with customers that required in-depth knowledge about the firm's products that were integrated with the customers' products. In addition, regular appointments with customers were needed in both pre- and after-sales phases to specify product requirements and give after-sales support.

Only in three cases $(\mathrm{G}, \mathrm{H}$, and $\mathrm{F})$, there were obvious connections between the nature of the different types of network relationships and the choice of the entry mode. In the case of Firm G, the entry mode choice was heavily influenced by their existing informal relationships with Japanese who liked to establish a joint venture with them. Firm H noticed that in their case, a successful market entry to the Japanese market required financial resources and local knowledge that they did not have. Therefore, they decided to sell their shareholding to the Japanese corporation and incorporate with them. This corporation was found by utilizing their existing formal relationship with the distributor in other markets. Firm F's entry mode choice was related to a distributor found with help of a mediated relationship, who thereafter started to distribute their products in Japan.

Table 3 sub-categorizes the case firms' target country and entry mode selection either into strategic decision or impact of the network relationships. 
Table 3

Impact of the network relationships to the target country and entry mode selection.

\begin{tabular}{ccccc}
\hline & \multicolumn{2}{c}{ Target country selection } & \multicolumn{2}{c}{ Entry mode selection } \\
& Strategic decision & Networks & Strategic decision & Networks \\
\hline Firm A & $\mathrm{X}$ & & $\mathrm{X}$ & \\
Firm B & & $\mathrm{X}$ & $\mathrm{X}$ & \\
Firm C & $\mathrm{X}$ & & $\mathrm{X}$ & \\
Firm D & $\mathrm{X}$ & & $\mathrm{X}$ & \\
Firm E & $\mathrm{X}$ & & $\mathrm{X}$ & \\
Firm F & $\mathrm{X}$ & & & $\mathrm{X}$ \\
Firm G & & $\mathrm{X}$ & & $\mathrm{X}$ \\
Firm H & $\mathrm{X}$ & & & $\mathrm{X}$ \\
\hline
\end{tabular}

\section{Discussion of Research Results}

As the findings of this study reveal, six out of eight firms actively developed new relationships or utilized their already existing contacts to reach opportunities in the Japanese market. This contradicts the assumption in the earlier studies that investigate general entry patterns, indicating that knowledge-intensive firms tend to reactively follow their existing formal or informal relationship to foreign markets (Bell, 1995; Coviello \& Munro, 1995, 1997; Coviello \& Martin, 1999; Moen et al., 2004; Sharma \& Blomstermo, 2003; Zain \& Ng, 2006). This kind of active network development to find new market opportunities is also reported in the study of Loane and Bell (2006). It is also related to opportunity seeking behavior of early and rapidly internationalizing firms (Oviatt \& McDougall, 1994). Passive networking, where firms followed their existing informal relationships to the Japanese market was evident only in two cases. This was a consequence of the managers' personal contacts, which initiated the firm's market entry to Japan.

Proposition 1: Knowledge-intensive SMEs actively develop new relationships or utilize existing ones to achieve the market entry to psychically distant markets.

This study reveals that the case firms used three different types of focal network relationships for their market entry. Two of the firms used formal relations with their distributors in other markets and two of the firms used informal relationships with friends. These findings are consistent with the earlier studies (Coviello, 2006; Coviello \& Martin, 1999; Coviello \& Munro, 1995, 1997; Westphal et al., 2006), which suggest that formal and informal relationships facilitate SMEs' internationalization activities. In addition, four of the firms' exclusively networked through mediated relationships with government-based non-profit consulting organizations. These mediated relationships proved very critical for those firms that did not have any existing formal of informal relationships that they could use for market entry. These findings are consistent, to a certain extent, with Havila et al. (2004) suggesting that firms use triadic relationships. However, unlike in the triad model of Havila et al. (2004), there were no business transactions between the buyer and the intermediary or between the seller and the intermediary in the case findings here. This highlights the importance of non-commercial organizations in the market entry of SMEs. This finding gives also empirical support to the 
conceptual study of Christensen and Lindmark (1993) indicating the importance of the role of non-commercial organizations.

Proposition 2: Knowledge-intensive SMEs without existing formal or informal relationships can take benefit from mediated relationships to achieve the entry to psychically distant markets.

The findings in this study indicate that different types of network relationships only had limited influence on the choice of Japan as the target country. Six of the eight case firms had made a strategic decision to enter the Japanese market without any influence of network partners. Only after this they started to actively search for available network relationships to achieve the market entry. This was because the Japanese market was seen as the major market for the firms' niche products. This is somewhat inconsistent with the earlier studies (Bell, 1995; Coviello \& Munro, 1995, 1997; Coviello \& Martin, 1999; Sharma \& Blomstermo, 2003; Zain \& Ng, 2006) that have solely investigated firms' initial market entries. This also contradicts the assumption in the network model (Johanson \& Mattsson, 1988) that existing network relationships are the major initiator for market selection. Thus, the finding indicates that when firms are entering attractive but distant markets for their products they are not passively following their networks to foreign markets. Instead, they are actively seeking for opportunities in the foreign markets and, thereafter, develop new networks or utilize existing networks to reach these opportunities. This is consistent with the international new venture theory (Oviatt \& McDougall, 1994) that highlights the opportunity seeking behavior of knowledge-intensive firms. This also supports the framework of Bell et al. (2003) and empirical findings of Ojala \& Tyrväinen (2007) suggesting that SMEs in knowledge-intensive sectors tend to enter leading markets early on in their internationalization process due to their niche product offering.

Proposition 3: In the entry to psychically distant markets, knowledge-intensive SMEs more likely select the target country without any influence of network partners and, thereafter, start to develop new relationships or utilize existing relationships to achieve the market entry.

In respect of entry mode choice, the case findings reveal that different types of network relationship had only a limited role when the firms selected their entry mode for the Japanese market. This finding somewhat contradicts with earlier studies (Coviello \& Munro 1995, 1997; Coviello \& Martin, 1999; Moen et al., 2004; Zain \& Ng, 2006) investigating only to the initial market entries and entry mode choices. Only in three out of eight cases, there were obvious connections between the network relationships used and the choice of entry mode. In other five cases, the entry mode choice in Japan was based on the firms' product strategy and requirements for implementation and after-sales support of nearby customers. Although some firms used indirect entry modes in the beginning, after a very short time period they started direct business operations in the market. This is in line with the study of Sharma and Blomstermo (2003) indicating that the entry mode choice of knowledge-intensive SMEs bases on the needs of the clients. These findings are also consistent with Bell's (1995, 1997) observation that the nature of a firm's product offering and complexity of software products is connected to firms' market entry strategies. It also supports the findings of Burgel and Murray (2000) which suggest that requirements for customer support affect the entry mode selection in high-technology industries. 
Proposition 4: Knowledge-intensive SMEs' entry mode choice in psychically distant markets is more related to strategic reasons to locate nearby customers than initiated by different types of network relationships.

\section{Conclusions}

This study contributes to the network model of internationalization (Johanson \& Mattsson, 1988) by recognizing the change in the networking activity in the internationalization behavior of knowledge-intensive SMEs. As the previous studies (Bell, 1995; Coviello, 2006; Coviello \& Munro, 1995, 1997; Coviello \& Martin, 1999; Moen et al., 2004; Sharma \& Blomstermo, 2003; Zain \& Ng, 2006) indicate, existing formal and informal network relationships drive firms to geographically and/or psychically nearby markets, because the firms tend to select their initial markets and entry modes by following their network relationships. However, findings here reveal that when knowledge-intensive SMEs enter distant markets, they more likely first select the target country and the entry mode without any influence of network partners. Thereafter, they start to develop new relationships or utilize existing relationships to achieve the market entry. Thus, a market entry and entry mode choice to a psychically distant market is more of a consequence of strategic reasons than that of initiation by network relationships.

A limitation of this study is that it focuses on a single industry and a single target country: the results of the qualitative multi-case study conducted might not be fully generalized. It should be considered that the Japanese market includes its own special characteristic and that the market differs remarkably (Ronen \& Shenkar, 1985) from the other main markets. For instance, these country specific characteristics might elevate the role of mediated relationships highlighted in this study. In addition, the software industry has it own characteristics due to the intangible nature of its products. Thus, the findings in this study need further validation related to other industries and markets. This study investigates solely the firms' focal network relationships dividing those into formal, informal, and mediated relationships. However, the firms might still use other types of relationships in addition to their focal, most important relationship. Thus, the relative importance and interaction between these relationships is not investigated here and a further study is needed to do it. The low amount of interviews per firm can also be seen as a limitation. However, recalling the small size of the firms at the time of the market entry to the Japanese market and the central role of the interviewed persons, these informants had the most valuable knowledge needed for this study.

From the managerial point of view, mediated relationships are a valuable resource for SMEs that do not have formal or informal network relationship available to facilitate their market entry to a psychically distant market. These firms can benefit from non-profit consulting firms when entering new markets and can use their connections for further networking in the target country. Furthermore, the findings indicate that managers should actively develop their network relationships to achieve market entry to the leading markets. If a firm only passively follows its networks to foreign markets, it might lose market opportunities in the leading markets and end up in countries where the real market potential is low. 


\section{References}

Almor, T. and Hashai, N. (2004). The competitive advantage and strategic configuration of knowledge-intensive, small- and medium-sized multinationals: a modified resource-based view, Journal of International Management, 10/4, 479-500.

Anderson, J.C., Håkansson, H. and Johanson, J. (1994). Dyadic Business Relationships Within a Business Network Context, Journal of Marketing, 58/4, 1-15.

Autio, E., Sapienza, H.J. and Almeida, J.G. (2000). Effects of age at entry, knowledge intensity, and imitability on international growth, Academy of Management Journal, 43/5, 909-924.

Bell, J. (1995). The Internationalization of Small Computer Software Firms: A Further Challenge to "Stage" Theories, European Journal of Marketing, 29/8, 60-75.

Bell, J. (1997). A Comparative Study of the Export Problems of Small Computer Software Exporters in Finland, Ireland and Norway, International Business Review, 6/6, 585-604.

Bell, J., McNaughton, R., Young, S. and Crick, D. (2003). Towards an Integrative Model of Small Firm Internationalisation, Journal of International Entrepreneurship, 1/4, 339-362.

Bilkey, W. and Tesar, G. (1977). The Export Behavior of Smaller-sized Wisconsin Manufacturing Firms, Journal of International Business Studies, 8/1, 93-98.

Birley, S. (1985). The Role of Networks in the Entrepreneurial Process, Journal of Business Venturing, 1/1, 107-117.

Burgel, O. and Murray, G.C. (2000). The International Market Entry Choice of Start-Up Companies in High-Technology Industries, Journal of International Marketing, 8/2, 33-62.

Cavusgil, S.T. (1980). On the internationalisation process of firms. European Research, 8/6, 273-281.

Chetty, S. and Blankenburg Holm, D. (2000). Internationalisation of small to medium-sized manufacturing firms: a network approach, International Business Review, 9/1, 77-93.

Christensen, P.R. and Lindmark, L. (1993). Location and Internationalization of Small Firms. In L. Lundqvist and L.O. Persson (eds.), Visions and Strategies in European Integration: A North European Perspective, Berlin: Springer-Verlag, 131-151.

Coviello, N. (2006). The network dynamics of international new ventures, Journal of International Business Studies, 37/5, 713-731.

Coviello, N.E. and Jones, M.V. (2004). Methodological issues in international entrepreneurship research, Journal of Business Venturing 19/4, 485-508.

Coviello, N.E. and Martin, K.A-M. (1999). Internationalization of Service SMEs: An Integrated Perspective from the Engineering Consulting Sector, Journal of International Marketing, 7/4, 42-66.

Coviello, N.E. and Munro, H.J. (1995). Crowing the entrepreneurial firm: Networking for international market development, European Journal of Marketing, 29/7, 49-61.

Coviello, N. and Munro, H. (1997). Network Relationships and the Internationalisation Process of Small Software Firms, International Business Review, 6/4, 361-386.

Crick, D. and Spence, M. (2005). The internationalisation of 'high performing' UK high-tech SMEs: a study of planned and unplanned strategies, International Business Review, 14/2, 167-185.

Dubini, P. and Aldrich, H. (1991). Personal and extended networks are central to the entrepreneurial process, Journal of Business Venturing, 6/5, 305-313.

Eisenhardt, K.M. (1989). Building Theories from Case Study Research, Academy of Management Review, 14/4, 532-550.

EITO (2006) European Information Technology Observatory 2006, Berlin, Germany. 
Ellis, P. (2000). Social Ties and Foreign Market Entry, Journal of International Business Studies, 31/3, 443-469.

Ellis, P. and Pecotich, A. (2001). Social Factors Influencing Export Initiation in Small and Medium-Sized Enterprises, Journal of Marketing Research, 38/1, 119-130.

Gabrielsson, M., Kirpalani, V.H.M., Dimitratos, P., Solberg, C.A., and Zucchella, A. (2008). Born Globals: Propositions to help advance the theory, International Business Review, 17/4, 385-401.

Gilmore, A., Carson, D., and Rocks, S. (2006). Networking in SMEs: Evaluating its contribution to marketing activity, International Business Review, 15/3, 278-293.

Harris, S. and Wheeler, C. (2005). Entrepreneurs' relationships for internationalization: functions, origins and strategies, International Business Review, 14/2, 187-207.

Havila, V., Johanson, J. and Thilenius, P. (2004). International business-relationship triads, International Marketing Review, 21/2, 172-186.

Johanson, J. and Mattsson, L-G. (1988) Internationalisation in Industrial Systems - A Network Approach. In N. Hood and J-E. Vahlne (eds.), Strategies in Global Competition, London: Croom Helm, 287-314.

Johanson, J. and Mattsson, L-G. (1992) Network positions and strategic action: an analytical framework. In B. Axelsson \& G. Easton (eds.), Industrial Networks: A New View of Reality, New York: Routledge, 205-217.

Johanson, J. and Vahlne, J-E. (1977). The internationalization process of the firm - a model of knowledge development and increasing foreign market commitments, Journal of International Business Studies, 8/1, 23-32.

Johanson, J. and Vahlne, J-E. (1990). The Mechanism of Internationalisation, International Marketing Review, 7/4, 11-24.

Johanson, J. and Vahlne, J-E. (1992). Management of Foreign Market Entry, Scandinavian International Business Review, 1/3, 9-27.

Johanson, J. and Vahlne, J-E. (2003). Business Relationship Learning and Commitment in the Internationalization process, Journal of International Entrepreneurship, 1/1, 83-101.

Johanson, J. and Wiedersheim-Paul, F. (1975). The internationalization of the firm: four Swedish cases, Journal of Management Studies, 12/3, 305-322.

Karppinen, M. (2006) Cultural Patterns of Knowledge Creation: Finns and Japanese as Engineers and Poets. Ph.D. dissertation, Helsinki School of Economics, Finland.

Loane, S. and Bell, J. (2006). Rapid internationalisation among entrepreneurial firms in Australia, Canada, Ireland and New Zealand, International Marketing Review, 23/5, 467485.

Lu, J.W. \& Beamish, P.W. (2001). The Internationalization and performance of SMEs. Strategic Management Journal, 22/6-7, 565-586.

Luostarinen, R. (1979). The Internationalization of the Firm. Ph.D. dissertation, Finland: Helsinki School of Economics.

Miles, M.B. and Huberman, A.M. (1994) Qualitative Data Analysis: An Expanded Sourcebook. California: Sage Publications.

Moen, O., Gavlen, M. and Endresen, I. (2004). Internationalization of small, computer software firms: Entry forms and market selection, European Journal of Marketing, 38/9-10, 12361251.

OECD (2003) Officially-supported export credits and small exporters. Organization for Economic Co-operation and Development, Paris, France. 
Ojala, A. (2008). Entry in a Psychically Distant Market: Finnish Small and Medium-sized Software Firms in Japan. European Management Journal, 26/2, 135-144.

Ojala, A. and Tyrväinen, P. (2007). Market Entry and Priority of Small and Medium-Sized Enterprises in the Software Industry: An Empirical Analysis of Cultural Distance, Geographical Distance, and Market Size, Journal of International Marketing, 15/3, 123-149.

Oviatt, B.M. and McDougall, P.P. (1994). Toward a theory of international new ventures. Journal of International Business Studies, 25/1, 45-64.

Oviatt, B.M. and McDougall, P.P. (2005). Defining international entrepreneurship and modeling the speed of internationalization, Entrepreneurship Theory and Practice, 29/5, 537-553.

Peltokorpi, V. (2007). Intercultural communication patterns and tactics: Nordic expatriates in Japan. International Business Review, 16/1, 68-82.

Ronen, S. and Shenkar, O. (1985). Clustering Countries on Attitudinal Dimensions: A Review and Synthesis, Academy of Management Review, 10/3, 435-454.

Rialp, A., Rialp, J., and Knight, G.A. (2005). The phenomenon of early internationalizing firms: what do we know after a decide (1993-2003) of scientific inquiry?, International Business Review, 14/2, 147-166.

Sharma, D.D. and Johanson, J. (1987). Technical Consultancy in Internationalisation, International Marketing Review, 4/4, 20-29.

Sharma, D.D. and Blomstermo, A. (2003). The internationalization process of Born Globals: a network view, International Business Review, 12/6, 739-753.

Westphal, J.D., Boivie, S. and Chng, D.H.M. (2006). The strategic impetus for social network ties: reconstituting broken CEO friendship ties, Strategic Management Journal, 27/5, 425445.

Yin, R.K. (1994) Case Study Research: Design and Methods. California: Sage Publications.

Zahra, S.A. \& Bogner, W.C. (2000). Technology Strategy and Software New Ventures' Performance: Exploring the Moderating Effect of the Competitive Environment. Journal of Business Venturing, 15/2, 135-173.

Zain, M. and Ng, S.I. (2006). The impacts of network relationships on SMEs' internationalization process, Thunderbird International Business Review, 48/2, 183-205. 